\title{
Chapter 9 \\ Emission Trading System and Forest: \\ Learning from the Experience of New Zealand
}

\author{
Benjamin Rontard and Humberto Reyes Hernandez
}

\begin{abstract}
In the area of international policy to mitigate climate change, the forest has been important in achieving the objectives of liable countries. The Emissions Trading System in New Zealand (NZ ETS) is the only case of an ETS integrating forestry as a mandatory actor. This is the result of prolonged political discussions and the characteristics of New Zealand forestry. Forest landowners are liable to surrender allowances for deforestation and can potentially receive allowances for the level of carbon sequestered. This scheme created new opportunities for forestry activities and impacted the decision-making trade-offs related to land-use changes. In Mexico, the implementation of an Emissions Trading System in 2020 is evidence of the country's commitment to controlling domestic emissions under the Paris Agreement. Nevertheless, for now, the forestry sector is not involved as a liable actor. It is possible to envision the integration of the forest sector because of the extensive forest cover in the country, which provides a livelihood for a large part of the population. Mexico has the experience and institutional framework to integrate forestry into national emission accounting and carbon forest projects in the voluntary market. The potential impacts of this integration are both positive and negative. Environmental impacts are positive because forest areas can help mitigate emissions, but intensive carbon farming disrupts native forests and biodiversity. The economic impacts would be highly favorable for forest landowners if market volatility were controlled, but there is a potential loss of public revenue for the State. Finally, carbon forestry has the potential to cause conflict between economic sectors involved in land use and among participating communities.
\end{abstract}

\footnotetext{
B. Rontard ( $\square)$

Programa Multidisciplinario de Posgrado en Ciencias Ambientales (PMPCA), Universidad Autonoma de San Luis Potosi (UASLP), Alvaro Obregon 64, Zona Centro, 78000 San Luis Potosí, SLP, México e-mail: benjamin.rontard@uaslp.mx

H. R. Hernandez

Facultad de Ciencias Sociales Y Humanidades, Universidad Autónoma de San Luis Potosí, Avenida Industrias \#101; Fracc. Talleres, C. P. 78494 San Luis Potosí. S. L. P., México e-mail: hreyes@uaslp.mx
} 
Keywords Forestry $\cdot$ New Zealand $\cdot$ Forest projects $\cdot$ Emissions trading system • Land-use change

\section{Introduction}

Deforestation and forest degradation have caused $30 \%$ of the anthropogenic $\mathrm{CO}_{2}$ accumulated in the atmosphere. However, forests are an essential component for achieving climate change targets since they capture one-third of current anthropogenic $\mathrm{CO}_{2}$ emissions (Federici et al. 2017). The United Nations has denounced the lack of commitment regarding forestry. Many countries have committed to achieve net-zero deforestation targets for the next decades, but very few of them have presented measures for doing so (United Nations Environment Programme 2019).

Article Five of the Paris Agreement presents the necessity to preserve and improve existing carbon sinks and support the development of a new source of carbon sequestration. Article Six highlights the importance of international cooperation in the development of mitigation schemes. Both articles are the successors of the treatment of Land Use, Land-Use Change, and Forestry (LULUCF) in the Kyoto Protocol. The text established the conditions for generating and trading Certified Emissions Reductions (CERs) or Emissions Reduction Units (ERUs) under Clean Development Mechanism (CDM) or Joint Implementation (JI) projects (UNFCCC 2009). Globally, units from forest activities only represent $0.5 \%$ of the total traded in carbon markets, and they are mostly from voluntary activities (Gren and Aklilu 2016).

The concept of Emissions Trading Systems (ETSs) or carbon markets is to commodify an ecosystem service or avoidance of environmental damage (GHG emissions). However, integrating carbon units from emissions permits and units for carbon sequestered into the same market assumes that they are similar products. This is reasonable because when buyers purchase carbon units in the secondary market, they correspond to emissions avoided somewhere else or carbon sequestered, which results in less carbon in the atmosphere.

ETS are the most popular response by governments to meeting their climate change targets. In 2020, there are 21 ETS in force and nine in the process of implementation (ICAP 2020). Some of them allow emissions to be offset with units from forest carbon projects or forestry CDM projects. The European Emissions Trading System (EU-ETS), currently the largest ETS, excludes the international units from carbon forest activities (European Commission 2020).

The EU-ETS omitted emissions and storage from LULUCF, but the Kyoto Protocol set the rules for net emissions accounting (Delbeke and Klaassen 2015). Under the Paris Agreement, the EU included LULUCF in the 2030 target. This target represents the third pillar of European climate policy after the EU-ETS and the Effort Sharing Regulation. The measures to support carbon sinks and limit emissions were integrated into the Common Agricultural Policy and seek to improve agricultural productivity and the provision of ecosystem services (Runge-Metzger 
and Wehrheim 2019). The New Zealand Emissions Trading Scheme (NZ ETS) is the only ETS that includes the forestry sector (ICAP 2020). NZ ETS covers 52\% of national emissions. The scheme includes the energy sector, industry, domestic aviation, transport, buildings, waste, and forestry.

In the NZ ETS, the different sectors do not respond to the price signal in the same way. Emissions from transport do not respond to carbon pricing as strongly as the other sectors do (Chris Livesey, personal communication 2020). The price sensitivity is not the same in the emitters sector as in forestry. In forestry, price incentive is efficient up to 19 USD to encourage carbon storage (which is close to the current price). However, it is not efficient enough to be an incentive for emissions abatement in industry and energy consumption. 60 USD is the estimated threshold where we could expect to observe a significant emissions reduction (Ollie Bolton, personal communication 2020). This gap in the price incentive demonstrates that units from carbon captured and units from emissions avoided are different economic products, and the relevancy of integrating them into the same scheme is limited.

In 2015, Mexico signed the Paris Agreement and presented its Nationally Determined Contribution (NDC) to the global target (United Nations 2015). Mexico set the target of reducing its greenhouse gas (GHG) emissions by $25 \%$ by the year 2030 compared to the business-as-usual scenario (Gobierno de la República 2015). Nevertheless, the Mexican ETS (Sistema de Comercio de Emisiones, ETS) does not integrate forestry as a liable sector. However, the scheme allows entities to offset up to $10 \%$ of their surrendering obligations with units from mitigation projects, which can include carbon forest projects (SEMARNAT 2019).

Mexico has plenty of forest resources, and reduction of emissions from LULUCF is essential to achieve international commitment. Nevertheless, the current political measures to increase the national carbon sink are fragile (Ranero 2018). The experience from other countries where ETS and policies to support carbon sequestration have been enforced represents an essential source of learning. Mexico is supported by international organizations in the implementation of the ETS and takes inspiration from other experienced ETS. Given the potential of forest resources and the recent launching of the ETS, observing the functioning of NZ ETS, and learning from it is an important step.

This chapter analyzes the potential for Mexico to establish an ETS with the inclusion of forestry and the likely impacts, using the experience of New Zealand. The first part describes the forestry sector in New Zealand and the functioning of the NZ ETS. The second part presents the forest resources in Mexico and the current political strategy in this sector. The third part tackles Mexico's strengths and weaknesses for the inclusion of forestry in the ETS and the potential impacts. 


\section{Forestry and the NZ ETS}

\section{Forestry in New Zealand}

The forest industry has been an essential factor for economic development in New Zealand. In consequence, native forests were impacted by European settlement. In the middle of the past century, the country started to massively plant exotic species, mostly Pinus radiata, to avoid deforestation of native species and to provide for domestic consumption and exportation of forest products (Ministry for Primary Industries 2020a). Pinus radiata is the most common exotic tree in New Zealand, covering $90 \%$ of forest plantations (New Zealand Forest Owners Association 2019).

Forest covered $80 \%$ of the country before Europeans started to arrive. At present, $38 \%$ of the land (10.1 million hectares) is covered by forest ( 8 million of native forest, and 2.1 million of exotic species). The government owns $75 \%$ of the native forest and the rest is under private ownership. The private land occupied by exotic species (1.7 million hectares) is available for production (Ministry for Primary Industries 2020a). In 2018, forestry activities produced USD4.7 billion (1.6\% of the national gross domestic product). The sector employs 35,000 people and is the third-largest exporting industry in the country after dairy and meat (Ministry for Primary Industries 2020b).

The Forest Act (1949) and the Resource Management Act (1991) set out the forestry rules. The government is not allowed to conduct any productive activity in the forest. Productive forestry plantation and logging activities are carried out on private property. New Zealand forestry is market-oriented and responds to price variation. In the mid-1990s, with a significant increase in the price of timber products, 300,000 ha of new forest area had been planted (Carver et al. 2017). Private forest landowners are mostly individuals who have a small holding. More than 2,000 smallholders are registered with the Farm Forestry Association (FFA), and some 10,000 are not affiliated. The Forest Owners Association (FOA) also includes more than 200 owners of large forest holdings (David Rhodes, personal communication 2020).

The FFA and the FOA represent $70 \%$ of harvest volume. The large landowners can be individuals, investors, forestry corporation, or Maori communities (Iwi). Two types of contracts (forest lease and forest right) allow forest landowners to transfer the rights for forest operation. A forestry lease is a leasing contract on a land title. This contract allows the beneficiary to occupy and take resources on the land. The owner of a forestry right has a property right on the trees but not on the land. Generally, this contract is preferred due to its simplicity of enforcement.

The Maori people have a spiritual and intergenerational relationship with the forest. While the occidental approach to forest heritage is on capital bequeath, they consider it a responsibility to past and future generations to preserve what the parents gave and to allow a future generation to live in the same world as the current one (Kingi 2008). Maori forest is held under individual private ownership, but for commercial activities, they join their lands through forestry trusts or corporations that can be either self-organized or under agreement with a forest company. Since land use and 
forest management is treated by means of a long-term approach in their culture, decision-making is a prolonged process.

\section{NZ ETS and Forest}

The NZ ETS was launched in 2008 after the enforcement of the Climate Change Response (Emissions Trading) Amendment Act. Agriculture is the only sector not covered by the program. However, this sector is the principal source of emissions. In $2018,45 \%$ of emissions reported at the national scale were from agriculture, meaning that the ETS covered 55\% of national emissions (Environmental Protection Authority 2019a). The NZ ETS works with upstream points of obligation, meaning that the upper part of the supply chain of the source of emissions is subject to forfeit allowances to the government. Forest landowners are points of obligation since deforestation is a direct source of emissions.

Forestry was the first sector in the NZ ETS. Integration of forestry into the NZ ETS seeks to promote carbon sequestration and storage by discouraging deforestation of pre-1990 forest and by encouraging the planting of the new post-1989 forest, replanting of the existing post-1989 forest, and increasing carbon density with longer harvest rotations. The government decided to distinguish pre-1990 and post1989 forest because of the Kyoto protocol scheme setting 1990 as the baseline year (Ministry for the Environment 2019). For the program, the definition of forest land is an area with at least $30 \%$ covered by forest species with at least $30 \mathrm{~m}$ of diameter on average (Ministry for Primary Industries 2020c). In 2018, there were 1,412,323 ha of exotic pre-1990 forest and 682,439 ha of post-1989 forest (Environmental Protection Authority 2019b).

Owners of land registered as forest area before 1990 are liable to surrender units for the quantity of carbon released when they deforest more than two hectares in five years. Indigenous forests are excluded from the NZ ETS since they are already protected by the Resource Management Act and the Forest Act (Karpas and Kerr 2011). The obligation is to notify the Ministry for Primary Industries of any deforestation, calculate the emissions, and surrender units. They can pay units directly to the government at a fixed price or buy them on the secondary market. It is also possible to offset deforestation by establishing an equivalent forest elsewhere (Ministry for Primary Industries 2017a).

Participation is voluntary for post-1989 forest owners. They can register their land with the NZ ETS and earn units during each obligation period (between one and five years) according to the net quantity of carbon captured. Until 2013, new participants could claim units according to the level of carbon captured from 2008. Since then, new participants receive units starting from their entrance into the NZ ETS (Carver et al. 2017). According to the evolution of the stock, the participant can earn or surrender units. In the case of total deforestation or if the owner wants to leave the NZ ETS, the participant must repay all units received.

Figure 9.1 illustrates the evolution of carbon storage for a single-age, single- 


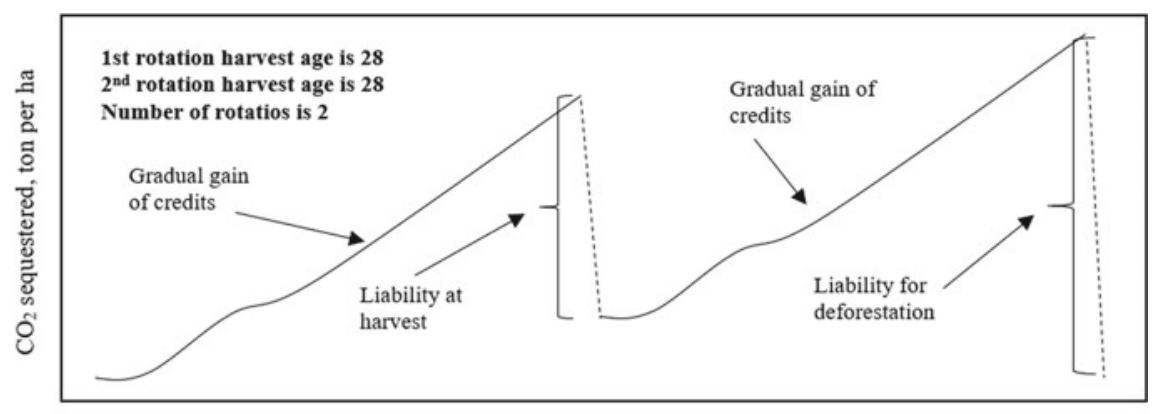

age

Fig. 9.1 Credits and liabilities over two forestry rotations (Karpas and Kerr 2011)

species forest planted in 2008 or later. It assumes harvest followed by replanting for the first rotation with a partial liability to surrender units, and harvest followed by land-use change for the second rotation with a total liability to surrender units.

The NZ ETS reform (2019) introduced a new accounting methodology based on averaging. Instead of gradually gaining credits until harvesting, participants will gradually gain credits until the average age and then receive a constant level of credits corresponding to the average level of carbon sequestered without liability at harvesting. The average age is the age at which the forest achieves the average level of carbon sequestered. This accounting seeks to simplify and reduce the cost of participation in the NZ ETS. Forest areas registered from January 2021 will apply this methodology, participants with forest registered in 2019 and 2020 will have the option to use it and forest registered before 2019 will continue with the previous methodology of stock change accounting (Ministry for Primary Industries 2020c).

The program uses tools provided by the Ministry for Primary for self-reporting. For pre-1990 deforestation reporting and post-1989 participants below 100 ha, the level of carbon stored is estimated by a look-up table (Ministry for Primary Industries 2017b) which is used to calculate the carbon released by deforestation and the evolution of the carbon stock by comparing to previous years. The calculation is based on information provided by participants (area, species, age, region). For post-1989 forest larger than 100 ha, the participants must use the Field Measurement Approach (FMA) (Ministry for Primary Industries 2018a). This instrument requires GPS data and detailed analysis on a sample plot, gathering data on tree diameters and heights, species, shrub types, crown cover, past and planned silvicultural activities, and adverse events (disease, fire, storm). The Ministry validates reporting processes for primary industries and may carry out audits and monitoring in the field or by remote sensing. Penalties for cheating or omitting information range from a monetary fine to a term of imprisonment up to five years according to the severity of the offense (Ministry for Primary Industries 2015a).

The scheme represented a high cost for pre-1990 forest owners if they planned to carry out land-use change or sell their land. As compensation for the loss of asset value, the government decided to give them a one-off free allocation, which is a 
fixed amount of allowances (Leining and Kerr 2018). The forest owners can use these units to meet their liability when they decide to deforest or sell them on the secondary market to receive a monetary payment.

Two complementary programs have been implemented by the government to substitute for participation in the NZ ETS: The Permanent Forest Sink Initiative (PFSI) and the Afforestation Grant Scheme (AGS). The PFSI seeks to improve conservation of post-1989 forest. Landowners who enter in the program sign a covenant with the government to definitively conserve their forest (with the possibility of withdrawing after 50 years). Limited harvesting is possible, but a minimum canopy cover must be maintained. Even if the landowner sells the land, the covenant stays in force (Ministry for Primary Industries 2015b). The landowner receives units according to the quantity of carbon stored, using the same reporting instrument. In 2021, the government will enforce the Climate Change Response (Emissions Trading Reform), which includes the end of the PFSI and transfers the participants to the NZ ETS in order to simplify the administrative process (New Zealand Government 2019).

The AGS was a grant distributed by the government to small and medium landowners for planting between five and 300 ha. The landowner receives USD 800 per hectare, and the government continues to receive the carbon units for the first ten years. After that, the forest enters into the NZ ETS (Carver et al. 2017). In 2019, the One Billion Trees Program replaced the AGS. This program operates with the same objective to promote new forest planting and native regeneration. Depending on the type of forest (native or exotic species), the landowner can receive between USD 320 and 2,500 per hectare. Landowners can participate in the NZ ETS unless they grow Pinus radiata, in which case the landowner can apply after six years (Ministry for Primary Industries 2018b).

\section{Participation and Impacts}

In 2018, 39 pre-1990 forest landowners were liable to surrender units corresponding to 74,363 tCO2e released ( $0.1 \%$ of total emissions covered by the NZETS). The same year, 2,106 post-1989 forest participants had registered 324,819 ha (48\% of the total). $94 \%$ of post-1989 forest participants are owners, $6 \%$ are forestry right-holders, and $1 \%$ are forestry leaseholders (Environmental Protection Authority 2019b). Most of the post-1989 forest landowners participating in the NZ ETS were already carrying out commercial logging activities, which gave them the possibility of having the capital to finance carbon farming.

Forestry right-holders or leaseholders are investors (individuals or companies) that have a contract with the forest landowners to share profit from carbon units or to pay a fixed rent. They represent a small portion of the number of participants but potentially cover a large part of the registered land. Since most of the forest landowners in New Zealand are smallholders, most NZ ETS participants are registered in small areas. Among the 2,206 participants in 2015, 1,439 listed between one and 49 ha covering 
Table 9.1 Distribution of pre-1989 forest participants by size class of forest (Carver et al. 2017)

\begin{tabular}{l|l|l|l|l}
\hline $\begin{array}{l}\text { Size class of } \\
\text { forest (ha) }\end{array}$ & $\begin{array}{l}\text { Number of } \\
\text { participants }\end{array}$ & $\begin{array}{l}\text { Percentage of } \\
\text { participants (\%) }\end{array}$ & $\begin{array}{l}\text { Total area } \\
\text { registered (ha) }\end{array}$ & $\begin{array}{l}\text { Percentage of land } \\
\text { registered (\%) }\end{array}$ \\
\hline $1-49$ & 1,439 & 65 & 26,000 & 9 \\
\hline $50-99$ & 353 & 16 & 22,000 & 7 \\
\hline $100-499$ & 343 & 16 & 66,000 & 22 \\
\hline $500-999$ & 24 & 1 & 14,000 & 4 \\
\hline $1,000+$ & 45 & 2 & 177,000 & 58 \\
\hline Total & 2,206 & 100 & 304,000 & 100 \\
\hline
\end{tabular}

only $9 \%$ of the total, while 45 participants registered more than 1,000 ha, which covered $58 \%$ of the total (Table 9.1).

The price increase in timber products prompted forest landowners to massively plant new forest areas between 1993 and 1996. In consequence, even if most of the new pre-1989 forest areas (planted after 2008) are registered in the NZ ETS, the most significant part of this area is forest planted before 2004 (Carver et al. 2017). It is hard to determine whether the NZ ETS had a material impact on pre-1990 deforestation and post-1989 afforestation. Previous empirical observations have shown that carbon pricing had a minimal impact on afforestation (Manley 2016). However, the carbon price is strongly affected by the volatility of the international market. In 2014, the price decreased by USD 3 but in 2015 the price of national units increased and has remained stable between USD 12 and 15 since 2018 (Leining and Kerr 2018).

At first, timber producers' participation in the NZ ETS was driven by a businessas-usual strategy. The recent evolution of the national carbon price encouraged registration of new forest areas (David Rhodes, personal communication 2020). Figure 9.2

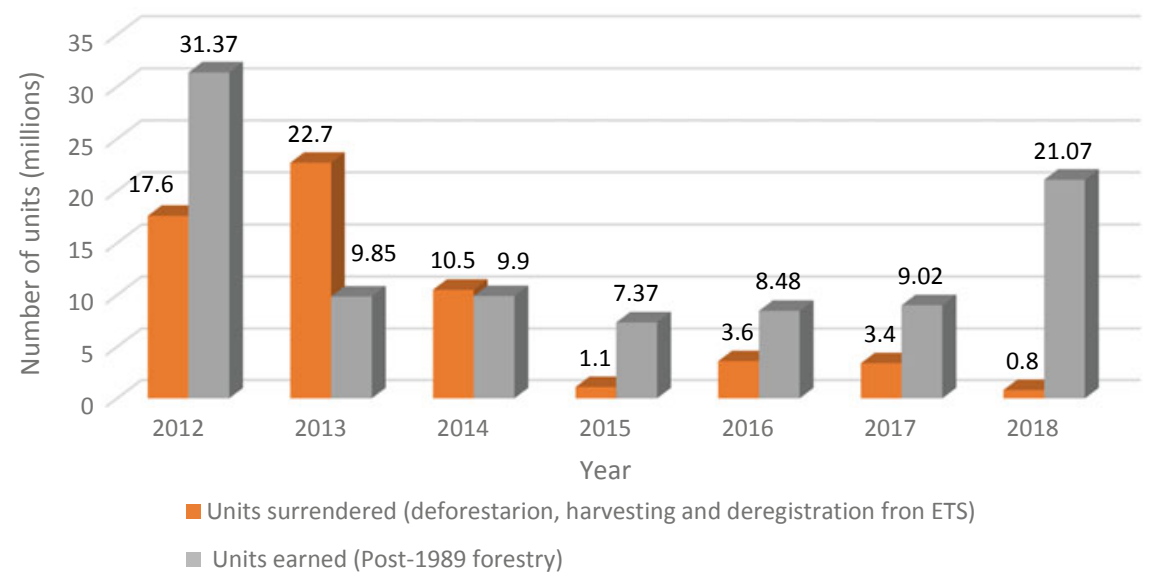

Fig. 9.2 Units earned and surrendered from forestry (millions) (Environmental Protection Authority 2019b) 
shows the evolution of units surrendered for deforestation, harvesting, or deregistration of post-1989 areas and units earned by post-1989 forestry. The effect of the carbon price on deforestation and harvesting is strong. However, the effect on removing activities is not immediate, probably due to the phenological stage of registered forest.

Nevertheless, there is an increase in post-1989 forest areas registered from 277,212 ha in 2014 to 324,819 ha in 2018 (Environmental Protection Authority 2015, 2019a, b). Planting of forests in New Zealand is not regular. The average new forest area planted was 100,000 ha per year as of 1990. At present, it is around 15,000 ha (Steven Cox, personal communication 2020). Experts are expecting a wave of harvesting in 2020 , followed by a considerable increase in planting.

\section{Forest and Climate Change Policy in Mexico}

\section{Forestry in Mexico}

Forest area covers $70 \%$ of the country (137.9 million hectares), but most of this area is dry forest. Current wooded forest areas in Mexico cover 65.7 million hectares, consisting of $52 \%$ of temperate forest, $45.7 \%$ tropical rainforest, and $1.4 \%$ mangrove (CONAFOR 2019). Deforestation in Mexico has been irregular. In the most recent decades, the deforestation rate decreased from $0.52 \%$ (1990-2000) to $0.10 \%$ (20102015) (Camara de Diputados and CEDRSSA 2019). The target under the Paris Agreement (Nationally Determined Contribution) is to reach a rate of $0 \%$ by the year 2030 (Gobierno de la República 2015). Deforestation varies from one type of forest to another. Most of the deforestation occurs in rainforest areas and is caused by landuse change for pastures, while dry forest areas have tended to increase in the most recent decades (Bonilla-Moheno and Aide 2020). At the national scale, land-use cover/change, and forestry (LULUCF) is the source of $4.9 \%$ of total GHG emissions (Ranero and Covaleda 2018).

Common property is dominant in the country (51\% of Mexican territory) and is the result of numerous agrarian reforms in the twentieth century, which impacted forestry management (Bray et al. 2006). However, most of the forest areas are under private ownership (50\%), while $45 \%$ are under communal ownership and 5\% state-owned (Reyes et al. 2012). Timber production is mostly carried out in common properties. 4.4 million hectares of forest with logging activity is under communal ownership and 1.1 million hectares under private ownership (CONAFOR 2019). The National Forest Commission also supports 220,000 ha of commercial planting in the country.

At the national scale, forestry is a weak activity $(0.23 \%$ of the gross domestic product in 2016), and imports of timber products are five times higher than exports. However, forestry has an essential social value in the country since the sector produces 166,664 jobs (CONAFOR 2019). Forest areas are an essential resource mainly for 
a large part of the population who depend on non-timber forest products for their livelihood.

Mexico had a purely productive vision of its forest until 1980 when it started to convert its national forest strategy into a sustainable logging and ecosystem conservation plan. In 2001, the country started a centralized plan for restoration and conservation of forests, support of timber and non-timber products for commercial purposes and livelihood through the creation of the National Forest Commission (CONAFOR 2001). Forest landowners (individuals and communities) can receive training, technical support, and subsidies from CONAFOR either for productive activities or conservation and restoration.

The iconic program is the payment for environmental services (PSA) program. This program was launched in 2003 with the goal of preserving hydrological services from forest funded with a fiscal instrument controlling water consumption, and payments are based on the opportunity cost of land (Muñoz-Piña et al. 2008). Payment can vary according to the region and type of forest. Currently, the maximum amount is around USD50 per hectare per year. The payment must fund technical support, which is compulsory in any CONAFOR program and restoration, reforestation, or conservation. The community can use the rest of the money for collective projects or investments (CONAFOR 2020). The PSA program supported 13,200 participants between 2003 and 2019, with total payments of USD 725 million (CONAFOR 2019). However, one of the limitations is budget availability. Figure 9.3 shows that the budget allocated decreased from USD 242 million in 2016 to USD 101 million in 2019.

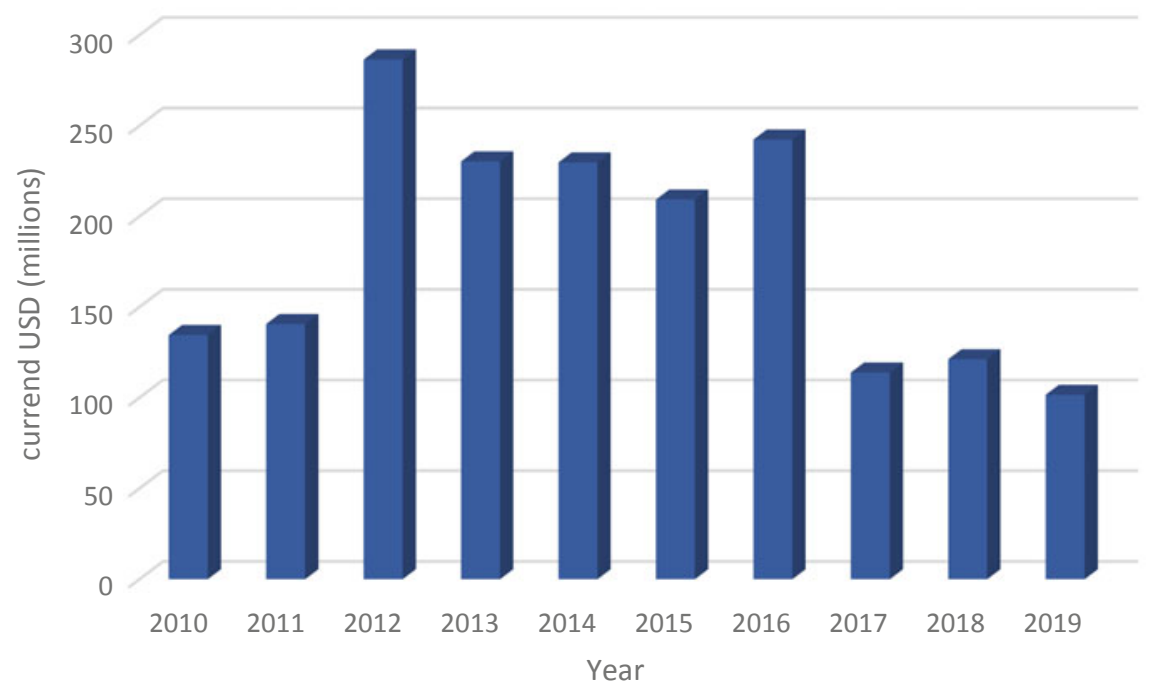

Fig. 9.3 Budget allocated to PSA program from 2010 to 2019 (current US dollars) (CONAFOR 2020) 


\section{Forest Carbon Policy in Mexico}

Mexico began hosting forest carbon projects soon after the Kyoto Protocol through the voluntary carbon market and REDD + program (Reducing Emissions from Deforestation and forest Degradation). Although Mexico is the second greatest recipient for Clean Development Mechanism (CDM) projects in Latin America and the fifth in the world, the country never hosted any carbon forest project under this scheme (MEXICO2 et al. 2018; Ranero and Covaleda 2018). The limitation in the EUETS to accept CDM offsetting only from Least Developed Countries (LDC) and the collapse of the price of Kyoto units after 2012 limited the opportunity for new CDM. Afforestation and reforestation (A/R) projects had not been successful under the CDM scheme because of methodological limits to unit accounting, the long-term process to generate units, and the compliance conditions to preserve carbon storage.

While forest carbon projects are almost absent in the CDM, they covered up to $35 \%$ of the credits offset in the voluntary carbon market between 2009 and 2016 (Ranero and Covaleda 2018). In Mexico, there have been carbon forest projects for the voluntary carbon market. Environmental organizations work with local communities and sell carbon units to private companies that want to offset their emissions certified under international standards (Rontard et al. 2020). Table 9.2 shows the projects in Mexico currently in force.

The Scolel'te project implemented in 1997 in the southern state of Chiapas involves 1,200 participants from 90 communities throughout the state covering 7,660 ha. The Cooperativa Ambio organization launched the project and worked directly

Table 9.2 Forest carbon projects in Mexico (Rontard et al. 2020)

\begin{tabular}{|c|c|c|c|c|}
\hline Project & State & Area (ha) & Standard & Organization \\
\hline $\begin{array}{l}\text { Sierra Gorda } \\
\text { Biodiversity Carbon }\end{array}$ & Querétaro & 21,491 & VCS - CCB & $\begin{array}{l}\text { Grupo Ecologico } \\
\text { Sierra Gorda }\end{array}$ \\
\hline San Juan Lachao & Oaxaca & 2,388 & $\begin{array}{l}\text { Climate Action } \\
\text { Reserve }\end{array}$ & ICICO A.C \\
\hline $\begin{array}{l}\text { Sustainable } \\
\text { Climate-Friendly } \\
\text { Coffee }\end{array}$ & Oaxaca & 292 & $\begin{array}{l}\text { Verified Carbon } \\
\text { Standard }\end{array}$ & UNECAFE S.C \\
\hline Carboin & Oaxaca & 3,000 & NMX-SSA-14064 & ICICO A.C \\
\hline $\begin{array}{l}\text { Captura de carbono } \\
\text { Santiago Coltzingo }\end{array}$ & Puebla & 3,092 & $\begin{array}{l}\text { Climate Action } \\
\text { Reserve }\end{array}$ & ICICO A.C \\
\hline $\begin{array}{l}\text { Captura de carbono } \\
\text { San Bartolo } \\
\text { Amanalco }\end{array}$ & Estado de Mexico & 1,005 & $\begin{array}{l}\text { Climate Action } \\
\text { Reserve }\end{array}$ & ICICO. AC \\
\hline Scolel'te & Chiapas & 7,660 & Plan Vivo & $\begin{array}{l}\text { Cooperativa } \\
\text { AMBIO }\end{array}$ \\
\hline $\begin{array}{l}\text { Fresh Breeze } \\
\text { Afforestation Project }\end{array}$ & $\begin{array}{l}\text { Tabasco, Nayarit, } \\
\text { Chiapas }\end{array}$ & 4,270 & $\begin{array}{l}\text { Verified Carbon } \\
\text { Standard }\end{array}$ & $\begin{array}{l}\text { Proteak UNO } \\
\text { S.A.B. de C.V }\end{array}$ \\
\hline
\end{tabular}


with the forest landowners. Participants are individuals, members of the communities, even if the forest area is officially communal property. They can harvest trees for logging activities without authorization from the Ministry of Environment (SEMARNAT), which provides them additional income if they respect the 25 years of commitment to Scolel'te.

The organization ICICO A.C. has been very active in setting up forest carbon projects in the last decade. Today, they manage four projects in three different states, and they are the first to develop a forest carbon project with the Climate Action Reserve standard (CAR). Unlike Cooperativa Ambio, they work with communities as a whole.

The government supports actions to encourage carbon storage in the forest through the ENAREDD + political framework. Since 2010, the Mexican government has been working on a strategy to develop a REDD + program across the country (Comisión Intersecretarial de Cambio Climático 2017). ENAREDD + seems to be the principal instrument used to meet Mexico's climate change targets in the forest sector. In REDD + programs, national governments are recipients of payments from other countries. The conditions to be met before starting the program are very strong. After ten years of national strategy design, Mexico has not launched and continues to work on the funding scheme.

\section{Integration of Forestry into the Mexican ETS}

The government has not made plans to include the forest sector in the Mexican ETS to date. However, integration of the forest sector has the potential to contribute to climate change targets and support rural communities. Mexico has points in its favor for developing a policy scheme like the NZ ETS. In this section, we present the strengths and weaknesses in the Mexican context to integrate forestry into the ETS and the potential impacts (positive and negative) that such integration would entail.

\section{Strengths in the Mexican Scheme}

The NZ ETS has done consistent regulatory work in the Climate Change Response (Emissions Trading) Amendment Act and has efficient public organizations such as the Ministry for Primary Industries, Ministry for the Environment, and Environmental Protection Authority. Mexico has gained experience in forest and ecosystem services policy. Over the years, this experience has enabled institutions and governmental organizations to develop their abilities to develop cross-sectoral policy on the national scale, such as the ETS.

Mexico was the first of the developing countries to have a regulatory framework to achieve climate change targets through the General Climate Change Act (SEMARNAT 2019). This law launched the creation of the National Emissions 
Registry (RENE) in 2013. Entities in the energy, industry, transport, agriculture, waste, commerce, or services sector who emit more than $25,000 \mathrm{tCO}_{2} \mathrm{e}$ per year are required to report their emissions in the RENE (Ramírez Bautista et al. 2016). The registry is based on self-reporting from entities following guidelines issued by SEMARNAT. Even if forestry is not included in the RENE, the institution would be able to establish a similar reporting instrument in this sector.

Since its creation in 2001, CONAFOR has showed its ability to manage forestry and ecosystem services. The 17 years of PSA and other forestry programs have strengthened CONAFOR functioning. Therefore, this institution should be able to manage the participation of forest landowners in the ETS as Ministry for Primary Industries does in the NZ ETS. Reporting process failures in New Zealand have been detected due to lack of knowledge about the methodology and liabilities. These failures are mostly due to landowners' mistakes and induce monetary sanctions more expensive than the cost of hiring a forestry consultant (David Rhodes, personal communication 2020).

Many landowners work without any technical support because the state limits interactions with landowners to avoid any influence in their decisions (Ollie Bolton, personal communication 2020). The Ministry for Primary Industries must deal with cases of non-compliance caused by lack of knowledge about the reporting process. Landowners also need support to understand market functioning in order to avoid losing money in the sale of carbon units. In Mexico, participants in CONAFOR programs must hire a forest technician to support landowners (CONAFOR 2020). The institution could teach landowners about program functioning. CONAFOR know-how and ability to train forest landowners could be a definite advantage in the integration of forestry into the ETS.

The experience from the forest carbon project in the voluntary carbon market must also be considered. Indeed, although these projects were developed without the participation of government institutions, they showed the ability of Mexican forest landowners to participate in carbon sequestration. These experiences also demonstrate the socioeconomic impact of carbon forestry on local communities. These internationally certified projects have robust technical requirements. The Mexican government could take these standards as a point of reference in implementing a methodology for accounting and monitoring the participation of the forest sector in the ETS. Data from these projects could give an estimate of the level of carbon sequestration and support the development of a national protocol (Ranero and Covaleda 2018).

Large forest areas in many communities are an advantage of Mexican land tenure. Fifteen thousand five hundred eighty-four communities in Mexico have more than 200 ha each. It means an opportunity to avoid the problem that smallholders face in the NZ ETS. When landowners register a small area, it is likely to contain the one unique stand of trees of the same age. Then, at harvesting time, they must surrender units for the totality of their registered area (Fig. 9.1). For them, the balance between harvest and growth is healthy. Large landowners have a different class and age of trees and compensate the surrendered units by units earned in another part of the land where it has not been harvested. In New Zealand, most of the participants with small 
areas are strongly exposed to this income volatility. Because of this, the government implemented averaging accountability. In Mexico, most of the communities with large forest areas can manage income stability.

\section{Weakness in the Mexican Scheme}

In the NZ ETS, most of the forest landowners are farmers who also do commercial logging, even on a small scale. However, in Mexico, commercial logging is not that common, and only a small portion of the communities with forest area have experience in forest management. Although the CONAFOR provides capacity-building and technical support in its programs, the lack of experience in forest management could cause two problems: failures in forest management and difficulty in investing in the first step of participation.

In the NZ ETS, participants have capital when they register their land because they already carry out farming and logging activities. The first income from carbon farming can take time because the land must pass the first report period and the participant must sell the distributed carbon units in the secondary market. It could be difficult for Mexican rural communities to finance the first investment and wait for the first income without any financial support.

Asymmetric information between stakeholders in the contracts is a problem of trust and uncertainty with commitment and price variation. Mexico is quite vulnerable to this issue, which limits the incentive to trade carbon credits from the forest (Van Kooten 2017). Illegal deforestation would represent a severe difficulty in the enforcement of unit surrendering. In Mexico, the Office for Environmental Protection (PROFEPA) identified 108 areas of illegal forest activity (SEMARNAT 2020). Illegal deforestation and forest degradation are mainly due to land-use change without authorization, illegal commercial logging commonly linked to organized crime, and extraction of non-timber products for livelihood or local commerce. It would be a challenging task to achieve compliance of unit surrendering in these zones where people have carried out extraction activities for a long time, and the law has not been enforced.

The NZ ETS experienced ups and downs in the incentive impact of carbon pricing in forest participation according to the variation of the unit price. The incentive impact depends on the cost of carbon farming activity and the potential income from alternative activities. In Mexico, the ETS will start with a total free allocation. The 300 participants will be allocated allowances based on historical emissions, and 5\% of the total available units may be sold by auction (MEXICO2 2019). Moreover, no economic sanctions will be enforced in the pilot phase (2020-2022). With this high level of free units and without sanctions for non-compliance, we can assume that the price of carbon units at auctions and in the secondary market will be quite low.

A low price would be insufficient to avoid deforestation and to support afforestation and reforestation at the same time. In current carbon pricing mechanisms, the prices are already low. In the voluntary carbon market, units from forest carbon 
projects are sold at around USD 10 (Leticia Espinosa, personal communication 2017), and the carbon tax for fossil fuel has a rate of USD $2.4 / \mathrm{tCO}_{2} \mathrm{e}$. In the NZ ETS, the limit from which the price of carbon units can have a potent incentive effect for forest landowners is at around USD 19 (Ollie Bolton, personal communication 2020).

There are also some political and macroeconomic limits on the integration of forestry into the ETS. In New Zealand, including forestry in the ETS and the international market was an opportunity to support an important sector of the national economy and resulted from political pressure from the forestry sector. In Mexico, forestry has always been an important economic sector, and forest areas were an opportunity to meet the Kyoto Protocol target because it was a positive carbon sink. In international negotiations, Mexico said it would include forestry in the international market. Under the Kyoto Protocol, the forest units were given to the government. However, the forest landowners pressured the government to receive these units. The forestry sector, through the FOA, put intense lobbying pressure on the government to include them in the NZ ETS (David Rhodes, personal communication 2020). In Mexico, the situation is different, and there is no political or economic interest in including forestry in the ETS. The forestry sector does not have any strong political influence in the country because it is not an important economic sector. The share of forest products in the GDP is shallow (0.23\% in 2016), and the level of imports in the forestry sector is five times the level of exports (CONAFOR 2019).

\section{Potential Impacts}

\section{Environmental Impacts}

The motivation to integrate forestry into the ETS is obviously to improve the level of carbon storage at the national scale. This would support achievement of the forestry target in regard to Mexico's climate change commitment. Moreover, the potential increase in forest area would support mitigation of Mexico's emissions and meet the country's NDC. There is severe environmental additionality in the distribution of carbon units for carbon sequestration in new forest areas. In New Zealand, most of the post-1989 forest participants were already carrying out logging activity, which was their incentive to make new plantations. Participation in the NZ ETS is a new source of income, but these forest areas could probably have been planted without it. In Mexico, besides CONAFOR programs, there is no incentive to reforest or plant new forest. Participation in the ETS by bringing income for new forest areas could be a net influence in the trade-off between forest and other land uses.

However, the environmental impact of carbon farming can also be harmful. Landowners participating in this activity are motivated to plant species with a high level of carbon sequestration. In New Zealand, Pinus radiata was the most commonly planted species because it is fast-growing and cheap to establish and to log. Additionally, it achieves a high level of carbon storage in a short time compared to native 
species. Today, $75 \%$ of the forest areas registered in the NZ ETS are planted with this species (Carver and Kerr 2017). However, native forests are essential because they are adapted to the local environment. These forests can provide more ecosystem services than carbon sequestration.

Native forests are composed of a high diversity of species and represent an essential habitat for other animal and plant species. Non-timber products from the native forest are also an essential resource for the livelihood of local populations in Mexico (Delgado et al. 2016). Moreover, the biodiversity of native species is vital for soil stability and water quality. Native forests have social and cultural value. For the local population, there is recreational interest in their conservation, and these forests can have spiritual value for indigenous people. The risk of encouraging planting for carbon sequestration is the substitution of native forests by more productive species.

\section{Economic Impact}

One of the first motivations for deforestation in Mexico is land-use change because communities do not earn income from their forests. Payment in the PSA program has been set according to the opportunity cost of forest areas (Muñoz-Piña et al. 2008). With time, livelihood support became more of a target than a positive externality of PES programs, and the marginalized population has been more likely to participate (Liu and Kontoleon 2018). The PSA has a small impact on poverty alleviation (Sims and Alix-Garcia 2017) because the payment is quite low, and forest conservation or planting has a high cost. There is also a limited number of recipients. The public budget limits the program, and available funds have been decreasing sharply.

In carbon forest projects, the income from the sale of carbon units would be enough to fund the projects and remunerate people working on them. However, it is still not enough to generate a sustainable income for the whole of participating communities. The advantage of the integration of forestry into the ETS is that the income would not depend on the public budget. As long as the unit sellers find buyers in the market, they will receive an income. In a way, it is a mechanism to collect private funding to support forest conservation and reforestation. In this scheme, the landowners must meet conditions to participate, but there is no limitation on the number of participants or forest area.

The income that participants will receive from the secondary market is exposed to price volatility. In the NZ ETS, unit price was quite unstable before 2015 because of variation in the price of international units (Leining and Kerr 2018). This volatility has been reflected in the participation of post-1989 forest and the deforestation of pre1990 forest (Carver et al. 2017). The government tackled this problem by delinking domestic ETS from the international carbon market. In Mexico, it would be necessary to have a mechanism to ensure income stability for forestry participants.

In the operation of the ETS, the government receives income when selling units through auctions, so distributing units to forest landowners for carbon sequestration can also have an impact on public revenue. The level of income from auction is 
proportional to the demand for carbon units. This income also depends on the proportion of free allocation, but this portion is decided by the government. If we assume the integration of forestry with more units distributed for carbon sequestration than units surrendered for carbon released, it will induce a larger supply of units in the secondary market, which will reduce the price and consequently the public revenue from auctions.

\section{Conflicts}

Carbon farming is an alternative economic activity and land use. Focusing on this activity means another activity is foregone. In New Zealand, a conflict grew between forestry and farmers. Farming is the largest economic activity in the country, and it also has a strong political lobby. The farmers' organization, 50 Shades of Green, has been struggling against the impact of the NZ ETS on land-use change. Farmers criticized investors buying farmland to convert into intensive forest plantations (Chalmers 2019). Foresters claim they have the right to plant forests to participate in climate change mitigation. However, the farmers highlight the economic loss to agriculture and the ecological impact of intensive forest plantation. The government must find a compromise between the first and third economic sectors.

In the Mexican voluntary carbon market, the carbon forest project created internal conflicts among the participant communities. In the Scolel'té program, conflicts rose between participants and non-participants because of the difference in land-use practices and the benefit they could obtain. In fact, participants can legally harvest their forest for commercial use after the commitment period ( 25 years). This practice generally requires harvesting authorization. Non-participants felt it unfair that other members in the same community could have more access to natural resources (Osborne 2015). However, this is specific to this program, where participants are individuals instead of whole communities. In communities with collective decisionmaking about land use and participation in carbon forest projects, this kind of conflict has not been detected (Rontard et al. 2020).

\section{Conclusion}

The NZ ETS model is unique because of the importance of the forestry sector in New Zealand's economy. Nevertheless, the scheme is still far from perfect and needs further improvement. Mexico has potential in its forest resources, the experience of existing institutions in forest management, and emissions registration. In other words, the country may be ready for the integration of forestry into the ETS. The carbon forest projects developed under the voluntary carbon market can be considered as a laboratory for their extension to the national scale. However, Mexican forest landowners are mostly communities with fragile technical knowledge about forest management. 
The forestry sector does not have the same political influence in the two countries. Unlike New Zealand, forestry is not an essential economic sector in Mexico. New Zealand has developed a standardized system to account for carbon storage. Mexico has not yet achieved this step. This offers an explanation as to why Mexico has not considered the inclusion of forestry in the ETS. The environmental effect will be helpful if the negative impacts of intensive carbon forestry are controlled. In the economic aspect, there is high interest in the communities benefitting from a new source of income, even if this resource would be exposed to market price volatility. Integrating forestry into the ETS induces prevented emissions and comparable carbon sequestering, while units from allowances to the industry and units from carbon forestry are similar economic products. This is arguable, regarding the difference in price incentives between forestry and other sectors in the NZ ETS. Integrating prevented emissions and sequestered carbon into the same market is a political choice, as is the use of an economic instrument to control environmental impacts.

Mexico has the potential to successfully enforce the integration of forestry into the ETS. Nevertheless, this task will require strong technical support for forest landowners from CONAFOR and significant investment for monitoring and verification. Finally, the integration of forestry into the NZ ETS is the result of socio-political discussion among the government, farmers, and forest landowners. In Mexico, it would be essential to establish a democratic process with the forestry sector and discuss its integration into the ETS with forest landowners and forestry organizations in the country.

Acknowledgements The principal author was hosted by Motu Economic and Public Policy Research, Wellington, to carry out this study. We acknowledge their support during this visit, especially the political and technical expertise of Catherine Leining.

\section{References}

Bonilla-Moheno M, Aide TM (2020) Beyond deforestation: land cover transitions in Mexico. Agric Syst 178:102734

Bray DB, Antinori C, Torres-Rojo JM (2006) The Mexican model of community forest management: the role of agrarian policy, forest policy and entrepreneurial organization. For Policy Econ 8(4):470-484

Camara de Diputados, CEDRSSA (2019) La Actividad Forestal en Mexico, Estrategias y Acciones contra la Deforestación. Palacio Legislativo San Lázaro, Ciudad de México. Octubre 2019

Carver T, Kerr S (2017) Facilitating carbon offsets from native forests (No. 1124-2019-2385)

Carver T, Dawson P, Kerr S (2017) Including forestry in an emissions trading scheme: Lessons from New Zealand

Chalmers H (2019) Lobby group 50 Shades of Green calls for pause on blanket forestry. Stuff. https://www.stuff.co.nz/business/farming/112878988/lobby-group-50-shades-ofgreen-calls-for-pause-on-blanket-forestry. Accessed 20 May 2020

Comision Intersecretarial de Cambio Climatico (2017) Estrategia Nacional para REDD+ 20172030. ENAREDD+

CONAFOR (2001) Programa Estratégico Forestal para México 2025. SEMARNAT-CONAFOR 
CONAFOR (2019) El sector Forestal Mexicano en Cifras 2019. Bosques para el Bienestar Social y Climático. SEMARNAT-CONAFOR

CONAFOR (2020) Reglas de Operación del Programa Apoyos para el Desarrollo Forestal Sustentable 2020. Diario Oficial Jueves 16 de enero de 2020

Delbeke J, Klaassen G (2015) Framing Member States' Policies. Delbeke/Vis (Hrsg.), 92-108

Delgado TS, McCall MK, López-Binqüist C (2016) Recognized but not supported: assessing the incorporation of non-timber forest products into Mexican forest policy. Forest Policy Econ 71:3642

Environmental Protection Authority (2015) 2014 facts and figures

Environmental Protection Authority (2019a) 2018 New Zealand emissions trading scheme report

Environmental Protection Authority (2019b) 2018 facts and figures.

European Commission (2020) Use of international units. EUROPA. https://ec.europa.eu/clima/pol icies/ets/credits_en. Accessed 15 Apr 2020

Federici S, Lee D, Herold M (2017) Forest mitigation: a permanent contribution to the Paris agreement? Working paper

Gobierno de la República (2015) Intended nationally determined contribution

Gren M, Aklilu AZ (2016) Policy design for forest carbon sequestration: a review of the literature. Forest Policy Econ 70:128-136

ICAP (2020) Emissions trading worldwide: status report 2020. International Carbon Action Partnership, Berlin

Karpas E, Kerr S (2011) Preliminary evidence on responses to the New Zealand forestry emissions trading system. Motu working paper no. 11-09. Motu working paper. Motu Economic and Public Policy Research.

Kingi T (2008) Maori landownership and land management in New Zealand. Making Land Work 2:129-151

Leining C, Kerr S (2018) Guide to the New Zealand emissions trading scheme. Report for the Ministry for the Environment (Motu, 2018)

Liu Z, Kontoleon A (2018) Meta-analysis of livelihood impacts of payments for environmental services programmes in developing countries. Ecol Econ 149:48-61. https://doi.org/10.1016/j. ecolecon.2018.02.008

Manley B (2016) Afforestation responses to carbon price changes and market certainties. University of Canterbury School of Forestry

MEXICO2, Environmental Defense Fund, IETA (2018) Mexico: a market based climate change policy case study

MEXICO2 (2019) México publica el límite de emisiones y asignaciones sectoriales para la fase piloto del ETS. MEXICO2. http://www.mexico2.com.mx/noticia-ma-contenido.php?id=420. Accessed 20 Apr 2020

Ministry for Primary Industries (2015a) Penalties and offences under the emissions trading scheme. Ministry for Primary Industries

Ministry for Primary Industries (2015b) Guide to the permanent forest sink. Ministry for Primary Industries

Ministry for Primary Industries (2017a) Offsetting deforestation of Pre-1990 forest land. MPI. https://www.mpi.govt.nz/growing-and-harvesting/forestry/forestry-in-the-emissionstrading-scheme/offsetting-deforestation-of-pre-1990-forest-land/. Accessed 12 Apr 2020

Ministry for Primary Industries (2017b) A guide to carbon look-up tables for forestry in the emissions trading scheme. Ministry for Primary Industries

Ministry for Primary Industries (2018a) A guide to the field measurement approach for forestry in the emissions trading scheme. Ministry for Primary Industries

Ministry for Primary Industries (2018b) One billion trees programme, our future our billion. New Zealand Government

Ministry for Primary Industries (2020a) New Zealand's forests. MPI. https://www.mpi.govt.nz/ growing-and-harvesting/forestry/new-zealand-forests-and-the-forest-industry/new-zealands-for ests/. Accessed 12 Apr 2020 
Ministry for Primary Industries (2020b) New Zealand's forest industry. MPI. https://www.mpi. govt.nz/growing-and-harvesting/forestry/new-zealand-forests-and-the-forest-industry/new-zea lands-forest-industry/. Accessed 12 Apr 2020

Ministry for Primary Industries (2020c) Emissions trading scheme improvements. MPI. https:// www.mpi.govt.nz/protection-and-response/environment-and-natural-resources/emissions-tra ding-scheme/emissions-trading-scheme-improvements/. Accessed 12 Apr 2020

Muñoz-Piña C, Guevara A, Torres JM, Braña J (2008) Paying for the hydrological services of Mexico's forests: analysis, negotiations and results. Ecol Econ 65(4):725-736

New Zealand Forest Owners Association (2019) New Zealand plantation forest industry facts and figures. NZFO Association (Ed.), 2018, 19

New Zealand Government (1991) Resource Management Act. New Zealand Government

New Zealand Government (2019) Climate Change Response (Emissions Trading Reform) Amendment Bill: Explanatory note. New Zealand Government

Osborne T (2015) Tradeoffs in carbon commodification: a political ecology of common property forest governance. Geoforum 67:64-77

Ramírez Bautista AJ, Maldonado Martínez MA, Morales Paredes G (2016) Guía de Usuario Registro Nacional de Emisiones (RENE), Para el Reporte de Emisiones de Compuestos y Gases de Efecto Invernadero. SEMARNAT-GIZ

Ranero A, Covaleda S (2018) El financiamiento de los proyectos de carbono forestal: Experiencias existentes y oportunidades en México. Madera y bosques, 24(spe)

Reyes JA, Gómez JP, Muis RO, Zavala R, Ríos GQ, Villalobos O (2012) Atlas de Propiedad Social y Servicios Ambientales en México. Instituto Interamericano de Cooperación para la Agricultura. Cooperación Técnica Registro Agrario Nacional - Instituto Interamericano de Cooperación para la Agricultura. México. $157 \mathrm{pp}$

Rontard B, Hernández HR, Robledo MA (2020) Pagos por captura de carbono en el mercado voluntario en México: diversidad y complejidad de su aplicación en Chiapas y Oaxaca. Sociedad y Ambiente 22:212-236

Runge-Metzger A, Wehrheim P (2019) Agriculture and forestry in the EU's 2030 climate target. Towards a climate-neutral Europe. Routledge, pp 165-179

SEMARNAT (2019) Programa de prueba del sistema de comercio de emisiones. 27 de noviembre de 2019. SEMARNAT. https://www.gob.mx/semarnat/acciones-y-programas/programa-de-pruebadel-sistema-de-comercio-de-emisiones-179414/. Accessed 11 May 2020

SEMARNAT (2020) Ilicitos forestales. SEMARNAT. http://dgeiawf.semarnat.gob.mx:8080/ibi_ apps/WFServlet?IBIF_ex=D4_R_PROFEPA01_03\&IBIC_user=dgeia_mce\&IBIC_pass=dge ia_mce. Accessed 11 May 2020

Sims KR, Alix-Garcia JM (2017) Parks versus PES: evaluating direct and incentive-based land conservation in Mexico. J Environ Econ Manag 86:8-28

United Nations (2015) Paris agreement

United Nations Environment Programme (2019) Emissions gap report 2019. UNEP, Nairobi

UNFCCC, U. N. (2009) Kyoto protocol reference manual on accounting of emissions and assigned amount. eSocialSciences

van Kooten GC (2017) Forest carbon offsets and carbon emissions trading: Problems of contracting. Forest Policy Econ 75:83-88 
Open Access This chapter is licensed under the terms of the Creative Commons Attribution 4.0 International License (http://creativecommons.org/licenses/by/4.0/), which permits use, sharing, adaptation, distribution and reproduction in any medium or format, as long as you give appropriate credit to the original author(s) and the source, provide a link to the Creative Commons license and indicate if changes were made.

The images or other third party material in this chapter are included in the chapter's Creative Commons license, unless indicated otherwise in a credit line to the material. If material is not included in the chapter's Creative Commons license and your intended use is not permitted by statutory regulation or exceeds the permitted use, you will need to obtain permission directly from the copyright holder.

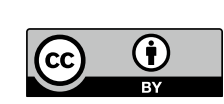

